\title{
Orassom - Preces Cantadas dos Mbyá-Guaranis*
}

\author{
Kilza Setti
}

Não é sem razão que os subgrupos Guaranis, como um todo, exercem tanto fascínio sobre os antropólogos, religiosos, etnólogos, historiadores etc. $\mathrm{O}$ crescente interesse da comunidade científica por esses povos tem rendido produção literária de apreciável valor. Não pude escapar a esse fascínio e me vejo, desde 1985, como aprendiz dos mistérios da música guarani, amarrada à área de antropologia da música.

Experiências religiosas, xamanismo, magia, sempre estiveram associadas à música em todas as culturas do mundo, mas o interesse em retomar este tema reside no empenho em esmiuçar particularidades de cada caso no estudo dessa interação mágicoterapêutica com práticas coreográficas, vocais e instrumentais. Aliás, essa interação ocorre não só nas culturas ditas tribais, mas também em sociedades ocidentais. Vêm-me à memória as abordagens psicológicas do antropólogo Ernesto de Martino sobre o que considerou construção cultural do mito tarântula, por ele estudado no sul da Itália (Puglia), e as práticas exorcistas que consistem em identificar e selecionar peças do repertório musical instrumental com suposto valor terapêutico para o tarantismo entre as mulheres. $\mathrm{O}$ fato foi visto pelo autor como produto histórico elaborado para enfrentar questões existenciais em áreas economicamente afetadas na Itália de pós-guerra dos anos 50 (De Martino, apud Magrini, 1994:66-79). 
No estudo das práticas músico-religiosas dos Mbyá-Guaranis (e Nhandeva-Xiripás), tenho procurado, sempre que julgo adequado, aproximar minhas próprias observações e dados de campo de estudos das de etnomusicólogos de outros países. No presente caso, separei alguns pontos que pretendo aqui considerar e que estão ligados à idéia de territorialidade e de espaço elementos de condição mínima para que uma cultura seja resguardada. Isto nos leva à questão do meio ambiente, e essa questão pode ser avaliada sob duas perspectivas:

1) O meio ambiente - espaço fisico enquanto gerador do conceito nativo de hugar/ espaço/ocupação/coletividade. Tomo aqui um exemplo absolutamente diferente do caso Mbyá, utilizando os estudos de Helen Reeves Lawrence sobre uma população de atol nas Ilhas Cook da Polinésia, uma situação, portanto, bastante singular e oposta à dos Mbyás. Os nativos do atol Manihiki têm um conceito de seu ambiente, a que chamam HENUA, e seu fazer musical está moldado às condições ambientais. O conceito HENUA desempenha, para eles, uma representação dual: HENUA - a terra, o povo, a morada, a ilha/abrigo, portanto, nos seus atributos físicos; e HENUA - no sentido de lugar a que se pertence (talvez num sentido abstrato, algo como a idéia de pátria para nós). Isolados na vastidão do Pacífico, a segurança que o atol thes oferece jamais poderá ser compreendida por povos continentais, como nós. As práticas de, após o parto, enterrar a placenta na reduzida porção de terra e, a seguir, plantar um coqueiro nessa terra, bem como o ritual de jogar os cordões umbilicais dos meninos e meninas recémnascidos, respectivamente, no mar que circunda o atol e na sua lagoa interna, definem a posse da terra e fixam a organização social em duas esferas, circunscrevendo o espaço das mulheres dentro e o dos homens fora do atol (Lawrence, 1995:13-22).

Com relação às idéias de ocupação, espaço etc., não valeria a pena repetir aqui a conhecida história das perdas dos Guaranis desde o contato e de como a sua territorialidade foi comprometida - fatos por demais conhecidos - , mas, em contraponto ao caso polinésio, vemos que os Mbyá-Guaranis desenvolvem também seu 
conceito de espaço, de território ideal, relacionado à sua cosmovisão, compondo assim uma espécie de "geografia mítica", que norteia suas constantes migrações (ver, por exemplo, o trabalho de Ladeira e Zibel Costa, 1992). Nos seus espaços considerados ideais, a que chamam TEKOA (num sentido talvez mais espiritual do que fisico), pode ser preservado o NHANDE REKO, isto é, "nosso modo de ser Mbyá". Os aldeamentos e as trilhas que os interligam são portanto considerados territórios propícios à manutenção do NHANDE REKO. Nesses territórios repousam seres ancestrais e neles teria sido criado o próprio cosmo Mbyá, algo talvez semelhante ao que chamamos Dreamland e Dreamtime a respeito dos aborígenes australianos, ou seja, a era da criação, que inclui mitos, ciclos de vida, paisagens, ambiente físico - enfim, o começo de tudo.

No Brasil sudeste, há que se considerar como pano de fundo ideal para os aldeamentos Mbyás, a Mata Atlântica, próxima ao litoral, que apresenta constantes ambientais e climáticas familiares a esses índios. Nas encostas da Serra do Mar e no Planalto, as neblinas que emanam da mata são identificadas à bruma vivificante (tataxina) e têm também correspondência com a fumaça dos cachimbos (petikwa), que cura e restaura a vida. Essa unidade ambiental lhes assegura um território ideal, onde lhes é permitido transitar não apenas fisicamente, mas comunicar-se com as diferentes regiões dos territórios sagrados - local da procedência da alma de cada indivíduo, dos compromissos do portador de cada nome em cumprir seu destino e responsabilidades TEKOÁ. Maria Inês Ladeira desenvolveu minucioso estudo sobre a classificação das almas, suas atribuições e talentos musicais. Há uma série de conexões entre "nome-alma" e aptidões musicais corrrespondentes. Cada região está associada a grupos de nomes e aos seus talentos para assumir funções musicais durante as cerimônias de comunicação com o divino (Ladeira, 1992:113-127).

Estas breves considerações a respeito do espaço, num sentido abstrato, permitem-nos portanto perceber a interdependência entre religiosidade, compreensão do cosmo, sistema de mitos e 
organização da música na sociedade Mbyá. Vimos no exemplo polinésio, o conceito de HENUA como lugar, "propriedade", a terra, o povo, o viver como Manihiki. Vimos o conceito Guarani de território e de como este resguarda o modo de ser dos Mbyás (NHANDE REKO).

2) Retomemos a questão do ambiente, mas agora enquanto entorno acústico, lugar de produção e armazenamento dos sons. Volto ao caso das Ilhas Cook. O espaço físico de atol propicia aos nativos ambiente sonoro peculiar, onde não há canto de pássaros (exceto gritos de andorinhas do mar), nem ruídos de sapos, grilos, cigarras ou outros insetos. Nesse nicho acústico, onde os sons se limitam ao barulho das folhas de coqueiros chocando-se ao vento, ao ruído do mar nas rochas, aos sons das ondas na areia e aos chamados das aves marinhas (de motivos rítmicos repetitivos e pouca variação nos padrões tonais), a voz humana assume papel preponderante e é usada em graus de visível intensidade. Reeves Lawrence verificou que a matéria-prima ambiental, no atol polinésio, fornece não apenas elementos naturais de confecção para instrumentos (tambores de pele de tubarão, chocalhos de conchas) mas identificou também uma inter-relação entre ambiente físico e estruturas musicais (Lawrence, 1995:19-21).

Trazendo a noção do entorno acústico para o contexto dos Mbyá-Guaranis, vemos que também eles desenvolvem idéias a respeito de um ambiente propício à sua expressão musical: o MBA'E PU, que Marília Godoy muito bem define como "Música - a comunicação com as divindades, e que compreende canto e dança" (Godoy, 1995:283).

$\mathrm{O}$ ambiente fisico da Mata Atlântica fornece a matéria-prima para a continuidade da prática musical (fibras, madeiras, cabaças, sementes, para a confecção dos instrumentos). O entorno acústico riquíssimo dessa região, reconhecida e notável por sua biodiversidade, pode determinar mesmo uma eventual estética musical Mbyá (tema importante, mas inadequado para ser tratado nesta rápida comunicação) e, com certeza, esse entorno pode determinar formas musicais. 
A propósito de formas musicais (e antes de falar das preces cantadas) cito o exemplo do XONDÁRO, forma instrumental relacionada à música cênica que se desenvolve em geral junto à casa de rezas (oó guaxu) e que tem, como fonte inspiradora, não só o padrão melódico do canto de determinadas aves, mas $a$ natureza dessas aves, suas características e seu valor na organização cósmica e mitica dos Mbyás. Alguns especialistas têm estudado a relação forma XONDÁRO com o vôo, a maneira de ser dessas aves e sua atuação no universo mítico dos Mbyás (ver M. I. Ladeira, 1992:143).

Em visitas que fiz às aldeias, recolhi material de muitas rezas. A análise dessa documentação permitiu-me verificar o seguinte: por exemplo, num corpo de seis exemplares de XONDÁRO, encontrei uma padronização quanto ao processo de afinação e uso das cordas da RAVÉ, mas diferentes procedimentos quanto à organização métrica em cada peça, o que suponho estarem relacionados aos diferentes pássaros: MAINÓ, o beija-flor, ave mítica; TAGUATÓ, o gavião; MBIJI, a andorinha. Ainda não posso assegurar certezas sobre o mensuralismo nessas peças em possível correspondência com os movimentos de cada pássaro. Mas, analisando peça por peça, encontro diferentes pulsações (de 4, 2 e 3 tempos simples ou compostos). Comprova-se também a extrema coerência interna dessas peças que mostram estruturação absolutamente simétrica. Num exemplar de XONDÁRO por mim recolhido em 1988, na aldeia de Barragem, encontrei a seguinte construção:

primeira seqüência: $\mathrm{AB}-\operatorname{coda}\left({ }^{*}\right.$ chamo de $\mathrm{A}$ e $\mathrm{B}$ dois tipos de células melódicas)

$\mathrm{AB}$ - coda

$\mathrm{AB}$ - coda

segunda seqüência: $A B-$ coda

$\mathrm{AB}-\mathrm{coda}$

$\mathrm{AB}$ - coda

terceira seqüência: $A B-$ coda

$\mathrm{AB}$ - coda

$\mathrm{AB}$ - coda 
quarta seqüência: $\mathrm{AB}$ - coda

$\mathrm{AB}$ - coda

$\mathrm{AB}$ - final, espécie de cadência, com final rall.

As formas de XONDÁRO com três pulsações mais parecem delicados minuetos Mbyás, onde a RAVÉ desenha melodias sob o apoio percussivo e reforçador do clima tonal dado pelo violão.

A forma de XONDÁRO parece situar-se no limite entre o profano e o sagrado, mas certamente está relacionada às preces sagradas que se constituem na essência do sistema musical Mbyá Guarani. Merece ser aqui considerada, uma vez que funciona como uma passagem às preces que têm lugar na OÓ GUAXU ou OPY. Embora as expressões coreográficas do XONDÁRO se limitem ao espaço externo, junto à casa de rezas, suas melodias seguem com a RAVÉ, incorporando-se às preces e contrapontando as vozes durante a madrugada até o amanhecer.

Falar das preces musicais Mbyás em poucas linhas será como apenas acenar para esse tema. A complexidade que as envolve exigiria horas de longas considerações. As preces musicais são chamadas PORAÍ. Do ponto de vista da lingüística e da mitologia, Ferreira Netto as classifica como "narrativas míticas" (F. Netto, 1994:101-3).

É sabido que os povos Guaranis estão voltados essencialmente para a palavra, a retórica, a eloqüência. Do ponto de vista estrito da etnomusicologia, os modelos das assim chamadas "narrativas míticas" acabam gerando matrizes musicais passiveis de serem analisadas sob aspectos de forma, conteúdo, simetria / assimetria, rítmica, contorno melódico, tendências tonais ou modais, usos de microtons, de cromatismos etc. Se analisados do ponto de vista da estrutura musical e fraseado, esses modelos, assim como o XONDÁRO, mostrarão padrões construtivos coerentes quanto à medida, organização intervalar, procedimentos vocais e instrumentais. Mas, a que ordem obedecem essas construções? E como definir sua lógica interna? É de se supor que os PORAÍ tenham 
sido modelados em arquétipos coletivizados, mas simultaneamente renovados a partir da performance de cada OPORAÍVA, de cada PAJÉ, e, nesse caso, particularizados pela ação individual. Seus textos são carregados de metáforas, o que os torna misteriosos e inacessíveis aos não-iniciados. As invocações, a que Cadogan chamou de "endechas"(Cadogan, 1959:83-4), situam-se num território neutro entre fala cantada e canto falado (o sprechgesang dos alemães), responsável pela ambigüidade que emana das rezas em certos momentos. Uma suposta opacidade dos textos (mencionada por Linda Barwick num estudo da música aborígene no sul da Austrália), resulta de canções míticas, cujos textos são formados por fragmentos de linguagens arcaicas, palavras incompreensiveis e às vezes indecifráveis pelos próprios músicos (Barwick, 1990:64-5). O caráter esotérico das palavras enigmáticas nem sempre é decifrável pelos músicos Mbyás. Aliás, Meliá define como experiência religiosa Guarani as formas do canto e da dança e a palavra profética, mais do que o conteúdo de suas crenças (Meliá, 1989:330). O PORAÍ é como que a chave que centraliza e reproduz todas essas formas mencionadas por Meliá, configurando-se ao mesmo tempo como forma musical, evento coletivo e celeiro da música tradicional Mbyá.

Complementa o clima de religiosidade dos PORAÍ, a atuação mágica dos instrumentos sagrados indispensáveis: MBARAKÁ, cabaça ressoadora, mencionada desde o século XVI entre os Tupis, de alto valor espiritual, cujo significado transcende o "humano", tornando-se veículo de comunicação com o "divino" (Métraux, 1979 e Fernandes, 1970); o MBARAKA-GUAXU, violão de cinco cordas com afinação e uso rituais; a RAVÉ, corruptela guaranizada da palavra rabel de três cordas (rabé, rabab etc. Ver Ruiz e Huseby, 1986); os YWIRAWY, pequenos bastões de madeira, que funcionam como idiofones quando se entrechocam (símbolo da masculinidade); e o TAKUAPU, bastão de ritmo, de uso exclusivo das mulheres. É este o elenco de instrumentos acompanhantes do PORAÍ. A ação músico-religiosa na busca da perfeição (AGUIJÉ) leva-os a estados de arrebatamento (cf. Dizia 
Schaden), e tal é o empenho em purificar-se através do canto e da dança que, durante as rezas, podem ocorrer situações de completa exaustão, até o desfalecimento de alguns fiéis.

Falar nas origens e trajetórias destas formas musicais seria entrar no terreno movediço das questões do contato, da colonização, da catequese: da submissão ou não dos Mbyás às missões jesuíticas - temas ainda efervescentes, mas muito polêmicos. Estudos mais recentes tendem a reforçar a hipótese de reação dos Mbyás ao contato com "encomenderos" ou missões. Meliá, embora reconheça que o cristianismo tenha introduzido idéias religiosas nos povos Guaranis, prefere atribuir a religiosidade desses índios às suas próprias experiências sociais e religiosas anteriores (Meliá, 1989:334. Ver também Mazzoleni, 1994).

Há, porém, algumas evidências. Ferreira Netto lembra a questão das técnicas colonialistas recomendadas para doutrinação, com o uso do TOM da língua nativa e posterior imposição das idéias do colonizador (F. Netto, 1994:30). Comprova-se, pois, que logo no início do contato, instalou-se entre os nativos o bilingïismo. Aliás, o bilingiuismo e pluriculturalismo tornaram-se mesmo condições indispensávers para uma sobrevivência física dos Guaranis e propiciaram um bimusicalismo ou phrimusicalismo - isto demonstrado pela facilidade com que os Mbyás e Guaranis, em geral, selecionam e absorvem determinados repertórios ocidentais, "compativeis" com suas próprias tendências estéticas - ainda que sua natureza introspectiva e contemplativa os predisponha muito mais a ouvir do que falar, e a organizar o pensamento e o discurso musicais preferencialmente no silêncio dos sons da mata.

O importante papel do PORAÍ Mbyá na pajelança é indiscutível. Estamos, porém, com um dilema: como situá-lo na sua configuração estritamente musical? A idéia de um produto híbrido parece por demais simplista e redutora, já que essas preces apresentam uma unidade formal surpreendente e se estendem desde Paraguai, Argentina, até o Brasil sul, sudeste e sudoeste e, pelo que pude verificar, consolidadas como um sistema musical religioso, ao qual se pode atribuir mesmo grande poder de coesão social e de 
resistência tribal. O conjunto de "narrativas míticas", palavras proféticas, crenças nos cataclismos, e outros sabores Mbyás, transita pelas aldeias embutido na prática da música e da dança. Estas, associadas à devoção e obsessão religiosas, têm função vital na manutenção do NHANDE REKO e no caminho para o YWY MARÃEI.

A população Guarani revela-se um caso absolutamente único na história do Brasil sudeste - região tão comprometida com processos civilizatórios e projetos desenvolvimentistas aniquiladores. Os Mbyás têm provado, ao longo dos séculos, que sua fragilidade cultural é apenas aparente.

\section{NOTA}

* Comunicação apresentada no VI Encontro Regional da Associação Brasileira de Psicologia Social - ABRAPSO-SP, "Emancipação e/ou Barbárie? Contribuições da Psicologia Social", realizada no periodo de 3 a 6 de julho de 1996.

\section{BIBLIOGRAFIA}

BARWICK, Linda. "Central Australian Women Ritual Music: Knowing Trhough Analysis Versus Knowing Trough Performances". Yearbook for Traditional Music, 22:60-79, 1990.

CADOGAN, Leon. "Como interpretan los Chiripá (Avá-Guarani) la danza ritual". Revista de Antropologia. São Paulo,(7) 1-2:65-99, 1959.

FERNANDES, Florestan. A Função Social da Guerra na Sociedade Tupinambá. São Paulo, Pioneira/Edusp, 1970. Coleção B.P.C.S. (Antropologia).

FERREIRA NETTO, Waldemar. Os Índios e a Alfabetização - aspectos da educação escolar entre os Guarani do Ribeirão Silvcira. São Paulo, 1994. Tese de Doutoramento, FFLCH-USP.

GODOY, Marília Ghizzi. Teko Axy: O Misticismo Guarani-Mbyá na Era do Sofrimento e da Imperfeição. São Paulo, 1995. Tese de Doutoramento, PUC-SP.

LADEIRA, Maria Inês. O Caminhar sob a Luz - o território Mbyá à beira do oceano. São Paulo, 1992. Dissertação de Mestrado, PUC/SP. 
e COSTA, Carlos Zibcl. "A geografia mítica Guarani-Mbyá - a concretitude físico-social do mundo (território) Guarani-Mbyá c o espaço mítico que o contém." Comunicação apresentada no Seminário Internacional O Novo Mapa do Mundo. São Paulo, USP, 1992.

LAWRENCE, Helen Reeves. "Music-making and the concept of Henua in an atoll environment". Yearbook for Traditional Music, 27:13-22, 1995.

MAGRINI, Tullia. "The Contribution of Ernesto de Martino to the Anthropology of Italian Music". Yearbook for Traditional Music, 26:6679, 1994.

MAZZOLENI, Gilberto. "Evangelização e tradições indígenas". RBCS, 26(9):66-71, out. 1994.

MELIÁ, Bartolomeu. "A experiência religiosa Guarani". O Rosto Índio de Deus. São Paulo, Vozes, 1989, p. 293-348. Séric VII, Desafios da Religião do Povo.

MÉTRAUX, Alfred. A Religião dos Tupinambás e suas Relações com as demais Tribos Tupi-Guaranis. São Paulo, Nacional/Edusp, 1979. (Brasilians, 267)

RUIZ, Irma e HUSEBY, Gerardo V. "Pervivencia del rabel europeo entre los Mbyá de Misiones". Temas de Etnomusicologia. Buenos Aires, Instituto Nacional de Musicologia "Carlos Vega", 2:67-97, 1986. SCHADEN, Egon. Aspectos Fundamentais da Cultura Guarani. São Paulo, EPU/ EDUSP, 1974.

Kilza Setti é compositora e etnomusicóloga. 